Folia Cardiologica 2018

\title{
Niewydolność serca - okres okołowypisowy kluczowym elementem postępowania
}

\section{Heart failure - discharge management the crucial point in heart failure care}

\author{
Małgorzata Lelonek \\ Zakład Kardiologii Nieinwazyjnej Uniwersytetu Medycznego w Łodzi
}

\section{Streszczenie}

Pacjenci po przebytym epizodzie ostrej niewydolności serca (HF) są często ponownie hospitalizowani. Wśród tych pacjentów występuje również wysoka śmiertelność - szczególnie w okresie od 60 do 90 dni po hospitalizacji. Każda kolejna hospitalizacja znacząco pogarsza rokowanie i zwiększa ryzyko zgonu pacjenta z HF, dlatego zapobieganie hospitalizacjom jest jednym z najważniejszych celów terapeutycznych w opiece nad pacjentami z HF. Okres okołowypisowy, z wczesnym włączeniem leków modyfikujących przebieg HF, jest w tej jednostce chorobowej kluczowy. W niniejszym artykule przedstawiono aktualny stan wiedzy na temat postępowania w okresie przedwypisowym oraz we wczesnej fazie po wypisaniu ze szpitala.

Słowa kluczowe: niewydolność serca, okres okołowypisowy

Folia Cardiologica 2018; 13, 4: 371-377

\section{Wstęp}

Według raportu OECD (Organisation for Economic Co-operation and Development) wskaźniki hospitalizacji pacjentów z powodu niewydolności serca (HF, heart failure) w Polsce należą do najwyższych [1]. W Polsce co czwarty chory wymaga rehospitalizacji w ciągu miesiąca od wypisania ze szpitala po zakończeniu hospitalizacji z powodu zaostrzenia $\mathrm{HF}$, a rocznie z powodu HF jest hospitalizowanych około 150 tys. pacjentów [2]. Niewydolność serca jest główną przyczyną hospitalizacji chorych po 65 . roku życia. Wydatki na leczenie HF w 2016 roku osiągnęły około $900 \mathrm{mln}$ zł [1]. Główną ich składową stanowią koszty hospitalizacji, które pochłonęły $94 \%$.

Hospitalizacja z powodu dekompensacji HF pozostaje niekorzystnym czynnikiem rokowniczym, jest bowiem powiązana z wysoką śmiertelnością w okresie rocznym oraz ryzykiem ponownych hospitalizacji z powodu HF, szczególnie nasilonych w okresie od 60 do 90 dni po opuszczeniu szpitala [3]. W literaturze opisano już vulnerable phase (fazę największej wrażliwości), czas od momentu wystąpienia ostrych objawów HF, przez cały okres hospitalizacji oraz okres okołowypisowy, do 6 miesięcy od wypisania ze szpitala [4]. Rokowanie pacjentów w okresie vulnerable phase jest poważne i wiąże się z podwyższonym ryzykiem ponownej hospitalizacji oraz zgonu. Szczegółowe aspekty kliniczne oraz terapeutyczne vulnerable phase opisano we wcześniejszym artykule autorki [5].

Ryzyko śmiertelności rocznej w HF jest tym wyższe, im więcej przebytych hospitalizacji w wywiadzie. Ryzyko zależy też od czasu trwania hospitalizacji oraz okresu, który upłynął od wypisania pacjenta ze szpitala (ryc. 1). W badaniu CHARM (Candesartan in Heart Failure: Assessment of Reduction in Mortality and Morbidity) wykazano, że główną przyczyną zgonów pacjentów z HF w ciągu roku po zakończeniu hospitalizacji była progresja HF - niewydolność serca jako pompy [3].

Wobec powyższych faktów postępowanie w okresach przedwypisowym i wczesnopowypisowym nabiera szczególnego znaczenia i wskazuje na konieczność włączenia

Adres do korespondencji: prof. dr hab. n. med. Małgorzata Lelonek FESC, Zakład Kardiologii Nieinwazyjnej, Uniwersytet Medyczny w Łodzi, ul. Żeromskiego 113, 90-549 Łódź, email: malgorzata.lelonek@umed.lodz.pl 


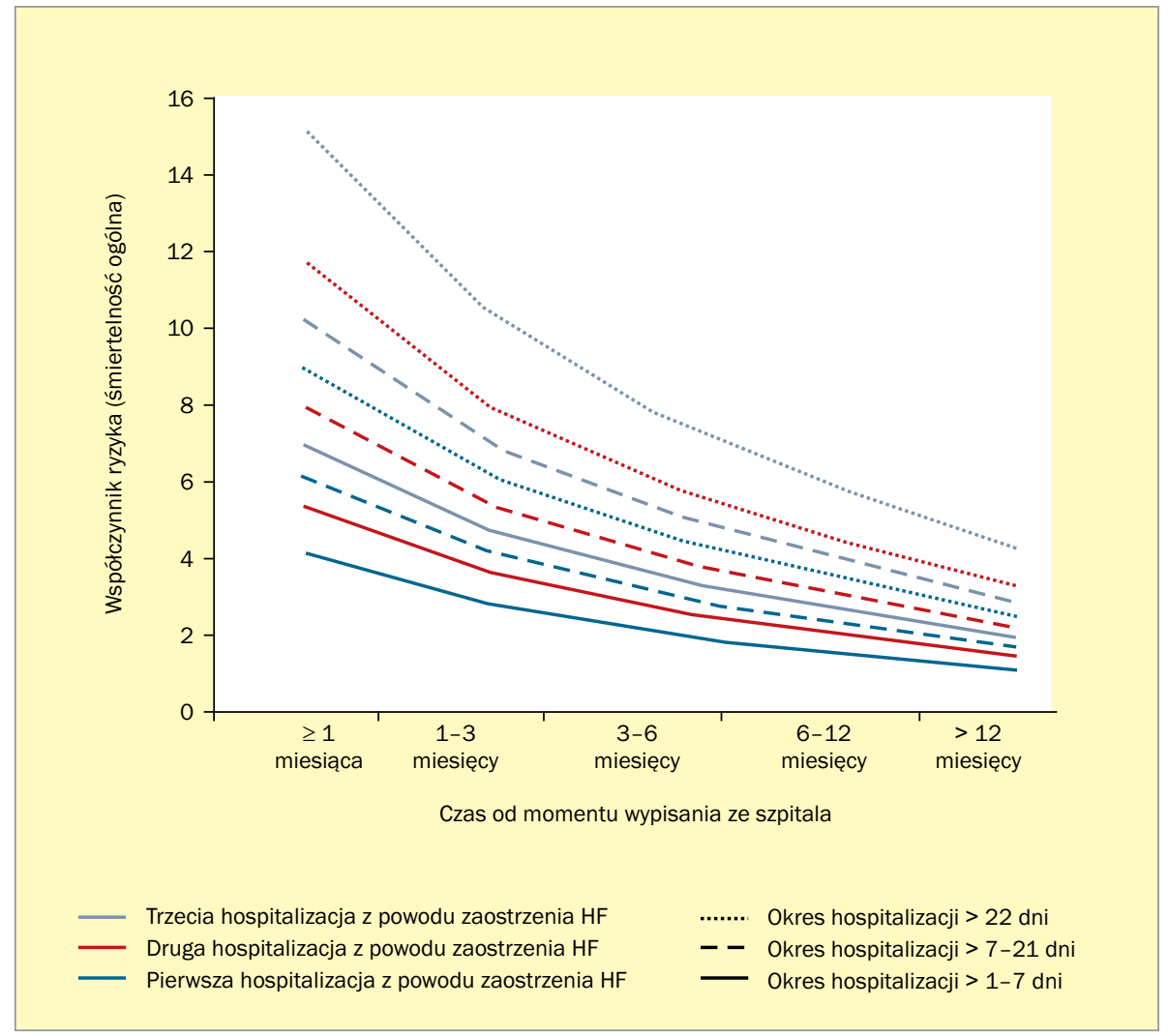

Rycina 1. Zależność śmiertelności ogólnej od liczby oraz długości hospitalizacji i czasu od ostatniej hospitalizacji (źródło [3])

w okresie okołowypisowym terapii modyfikujących przebieg HF, czyli wpływających na poprawę rokowania i zmniejszenie liczby rehospitalizacji.

\section{Postępowanie w okresie przedwypisowym}

Zalecenia dotyczące zasad planowania wypisu u pacjenta hospitalizowanego z powodu ostrej HF opracowały Heart Failure Association i Acute Cardiac Care Association (tab. 1) [6, 7].

Postępowanie terapeutyczne $u$ chorych z nowo rozpoznaną HF jest zazwyczaj nieco inne niż u pacjentów z zaostrzeniem w przebiegu przewlekłej HF. W HF de novo należy odpowiedzieć na pytanie, co jest przyczyną wystąpienia HF, natomiast w dekompensacji przewlekłej HF - zastanowić się, jak zmodyfikować dotychczasowy schemat leczenia, by poprawić rokowanie pacjenta i zapobiec kolejnym hospitalizacjom. W nowo rozpoznanej HF zwykle pacjentom podaje się mniejsze dawki leków modyfikujących przebieg choroby (rozpoczęcie leczenia) niż chorym z zaostrzeniem przewlekłej HF.

Postępowanie powinno uwzględniać zalecenia niefarmakologiczne i farmakologiczne oraz ustalenie wskazań do elektroterapii czy leczenia inwazyjnego zgodnie z wytycznymi European Society ofa Cardiology (ESC) [8]. Leki
Tabela 1. Kryteria planowania wypisu i postępowania w okresie powypisowym (na podstawie [6])

Planuje się wypisanie pacjenta hospitalizowanego z powodu ostrej niewydolności serca (HF, heart failure) jeśli:

1. jest stabilny hemodynamicznie, euwolemiczny, wprowadzono u niego terapię doustną lekami wg zasad EBM i funkcja nerek pozostaje $u$ niego stabilna przez $\geq 24 \mathrm{~h}$ przed wypisaniem

2. poddano go edukacji i poinformowano o zasadach samokontroli.

Pacjent powinien zostać objęty programem leczenia HF z wizytami kontrolnymi:

3. u lekarza POZ w ciągu tygodnia od wypisania

4. u kardiologa (najlepiej z oddziału, na którym był hospitalizowany) w ciągu 2 tygodni.

Pacjent z przewlekłą HF powinien być pod opieką zespołu specjalizującego się w HF

EBM (evidence-based medicine) - medycyna oparta na dowodach naukowych; POZ - podstawowa opieka zdrowotna

modyfikujące przebieg niewydolności serca z obniżoną frakcją wyrzutową (HFrEF, heart failure with reduced ejection fraction), to jest inhibitory konwertazy angiotensyny (ACE, angiotensin-converting enzyme), antagoniści receptora 
Tabela 2. Dawki początkowe i docelowe leków modyfikujących przebieg HF (źródło [8])

\begin{tabular}{|c|c|c|}
\hline & $\begin{array}{l}\text { Dawka początkowa } \\
\text { [mg] }\end{array}$ & $\begin{array}{l}\text { Dawka docelowa } \\
\text { [mg] }\end{array}$ \\
\hline \multicolumn{3}{|c|}{ Inhibitory konwertazy angiotensyny } \\
\hline Kaptopryl ${ }^{a}$ & $3 \times 6,25$ & $3 \times 50$ \\
\hline Enalapryl & $2 \times 2,5$ & $2 \times 10-20$ \\
\hline Lizynopryl $^{\mathrm{b}}$ & $2,5-5,0$ & $20-35$ \\
\hline Ramipryl & 2,5 & 10 \\
\hline Trandolapryl $^{a}$ & 0,5 & 4 \\
\hline \multicolumn{3}{|c|}{ Leki $\beta$-adrenolityczne } \\
\hline Bisoprolol & 1,25 & 10 \\
\hline Karwedylol & $2 \times 3,125$ & $2 \times 25^{d}$ \\
\hline $\begin{array}{l}\text { Bursztynian meto- } \\
\text { prololu (CR/XL) }\end{array}$ & $12,5-25$ & 200 \\
\hline Nebiwolol $^{c}$ & 1,25 & 10 \\
\hline \multicolumn{3}{|c|}{ Antagoniści receptora dla angiotensyny } \\
\hline Kandesartan & $4-8$ & 32 \\
\hline Walsartan & $2 \times 40$ & $2 \times 160$ \\
\hline Losartan ${ }^{\mathrm{b}, \mathrm{c}}$ & 50 & 150 \\
\hline \multicolumn{3}{|c|}{ Antagoniści receptora mineralokortykoidowego } \\
\hline Eplerenon & 25 & 50 \\
\hline Spironolakton & 25 & 50 \\
\hline \multicolumn{3}{|c|}{$\begin{array}{l}\text { Antagonista receptora dla angiotensyny } \\
\text { i inhibitor neprilizyny - ARNI }\end{array}$} \\
\hline $\begin{array}{l}\text { Sakubitryl/ } \\
\text { /Walsartan }\end{array}$ & $2 \times 49 / 51$ & $2 \times 97 / 103$ \\
\hline \multicolumn{3}{|l|}{ Inhibitor kanału If } \\
\hline Iwabradyna & $2 \times 5$ & $2 \times 7,5$ \\
\hline $\begin{array}{l}\text { Dawka docelowa pochodzi z } \\
\text { awka w porównaniu z mniejsz } \\
\text { miertelności, brakuje jednak } \\
\text { ych i optymalne dawkowanie } \\
\text { a śmiertelność sercowo-naczy } \\
\text { kazało się nie gorsze wobec le } \\
\text { toże być stosowana u pacjent }\end{array}$ & $\begin{array}{l}\text { ań klinicznych u pacjentów po przz } \\
\text { lawką tego samego leku spowoddo } \\
\text { ych z randomizowanych kontrolo } \\
\text { zostało ustalone; 'Leczenie z ne } \\
\text { wą lub całkowita u pacjentów z } \\
\text { enia o takiej skuteczności); 'Mak } \\
\text { ważących powyżej } 85 \mathrm{~kg}\end{array}$ & $\begin{array}{l}\text { oytym zawale serca; 'Wiekszza } \\
\text { alła redukcję chorobowości/ } \\
\text { anych placebo badań klinicz- } \\
\text { okkumentowanym whywem } \\
\text { wydolnościa serca (lub które } \\
\text { malna dawka } 2 \times 50 \mathrm{mg}\end{array}$ \\
\hline
\end{tabular}

AT1 dla angiotensyny II (ARB, angiotensin receptor blocker), leki beta-adrenolityczne, antagoniści receptora mineralokortykoidowego (MRA, mineralocorticoid receptor antagonists) i iwabradyna z zakresami dawek początkowych i docelowych przedstawiono w tabeli 2. Skuteczność leczenia w redukcji ryzyka zgonu i hospitalizacji zależy od zastosowanych dawek leków, dlatego istotna jest zasada optymalizacji terapii i dążenie do dawek docelowych leków modyfikujących przebieg HFrEF.

Niekorzystnym czynnikiem rokowniczym przy wypisaniu jest wysoka częstość rytmu serca. Zwolnienie częstości rytmu serca jest jednym z podstawowych celów terapeutycznych w leczeniu HFrEF [8]. U 70\% pacjentów z HF wypisywanych ze szpitala odnotowano częstość rytmu serca większą lub równą 70/min [9]. U części chorych już na etapie szpitalnym może być w takiej sytuacji przydatne dołączenie iwabradyny do leczenia beta-adrenolitykami $[10,11]$. Tego typu strategia wydaje się korzystna dla pacjentów z rytmem zatokowym i częstością rytmu większą lub równą 70/min, hospitalizowanych po raz kolejny z powodu zaostrzenia HF. Ponowna hospitalizacja wskazuje, że dotychczasowa strategia leczenia okazała się nieskuteczna i nie daje możliwości uniknięcia ponownego pobytu w szpitalu bez modyfikacji terapii. W badaniu ETHIC-AHF udowodniono, że intensyfikacja leczenia z wczesnym równoczesnym podawaniem leków beta-adrenolitycznych i iwabradyny chorym ustabilizowanym po dekompensacji powoduje istotne zwolnienie częstości rytmu, co było oceniane po 28 dniach oraz 4 miesiącach [10]. Korzyści z wczesnego stosowania iwabradyny przed wypisaniem ze szpitala u pacjentów hospitalizowanych z powodu HF wykazali badacze OPTIMIZE HEART FAILURE CARE PROGRAMME [11]. W rocznej obserwacji udokumentowano redukcję ryzyka zgonu i hospitalizacji z powodu HF (współczynnik ryzyka [HR, hazard ratio] 0,45; 95-proc. przedział ufności [Cl, confidence interval] 0,32-0,64; $p<0,0001$ ), większy odsetek pacjentów przyjmujących leki beta-adrenolityczne $\mathrm{w}$ dawce przekraczającej 50\% dawki docelowej (82,0\% v. 66,6\%; $p=0,0001)$ oraz lepszą jakość życia $(p<0,0001)$ dla chorych leczonych beta-adrenolitykami i iwabradyną [11].

Okres przedwypisowy zazwyczaj nie pozwala na osiągnięcie dawek docelowych, dlatego po wypisaniu ze szpitala konieczne jest stopniowe zwiększanie dawek leków do osiągnięcia dawek docelowych lub maksymalnej dawki tolerowanej przez chorego. Podstawowa rola w tych działaniach należy do lekarza podstawowej opieki zdrowotnej (POZ). Przydatnym narzędziem w zakresie zasad optymalizacji leczenia HF po zakończeniu hospitalizacji jest „List do lekarza POZ”, którego wzór przedstawiono na rycinie 2 .

Kolejnym ważnym elementem postępowania w okresie przedwypisowym z kontynuacją po wypisa jest optymalne leczenie schorzeń współistniejących, czyli opieka interdyscyplinarna [8]. Z kolei zasady postępowania w okresie okołowypisowym przedstawiono w tabeli 3.

\section{Zalecenia po zakończeniu hospitalizacji}

W literaturze wykazano, że wprowadzenie rutynowych wizyt monitorujących 7. dnia po zakończeniu hospitalizacji z powodu HF zmniejsza częstość ponownych hospitalizacji w okresie 30 dni o 30\% [12, 13]. Metra i wsp. [14] dowiedli, że śmiertelność 30-dniowa po hospitalizacji w istotnym stopniu zależy od opieki poszpitalnej i jest najniższa w odniesieniu do strategii wizyt kontrolnych u lekarza POZ i kardiologa.

Istotnym problemem w opiece poszpitalnej jest osiąganie dawek docelowych terapii modyfikującej przebieg HF. Z danych polskich pacjentów rejestru QUALIFY wynika, 


\section{Szanowny Panie Doktorze/Szanowna Pani Doktor,}

Zgodnie z wytycznymi Europejskiego Towarzystwa Kardiologicznego z 2016 roku optymalizacja terapii po hospitalizacji z powodu ostrej niewydolności serca (HF) zmniejsza ryzyko wystąpienia ponownych hospitalizacji, śmiertelności sercowo-naczyniowej oraz poprawia jakość życia. Poniżej zamieszczono praktyczne wskazówki dotyczące farmakoterapii oraz zaleceń pozafarmakologicznych dla pacjenta z HFrEF.

1. Optymalizuj leczenie farmakologiczne - zwiększaj dawkę B-blokera oraz ACEi/ARB co 2-4 tygodnie pod kontrolą częstości rytmu serca i ciśnienia tętniczego do dawki docelowej lub dawki maksymalnej tolerowanej przez pacjenta.

\begin{tabular}{|c|c|c|c|}
\hline ACEi & Dawka docelowa & B-adrenolityk & Dawka docelowa \\
\hline Kaptopryl & $3 \times 50 \mathrm{mg} / \mathrm{d}$ & Bisoprolol & $1 \times 10 \mathrm{mg} / \mathrm{d}$ \\
\hline Enalapryl & $2 \times 10-20 \mathrm{mg} / \mathrm{d}$ & Karwedylol & $2 \times 25-50 \mathrm{mg} / \mathrm{d}$ \\
\hline Lizynopryl & $1 \times 20-35 \mathrm{mg} / \mathrm{d}$ & \multirow{2}{*}{$\begin{array}{l}\text { Bursztynian } \\
\text { metoprololu }\end{array}$} & \multirow[t]{2}{*}{$1 \times 200 \mathrm{mg} / \mathrm{d}$} \\
\hline Ramipryl & $2 \times 5 \mathrm{mg} / \mathrm{d}$ & & \\
\hline Trandolapryl & $1 \times 4 \mathrm{mg} / \mathrm{d}$ & Nebiwolol & $1 \times 10 \mathrm{mg} / \mathrm{d}$ \\
\hline ARB & Dawka docelowa & ARNI & \\
\hline Kandesartan & $32 \mathrm{mg} / \mathrm{d}$ & Sakubitryl/walsartan & $2 \times 97 / 103 \mathrm{mg}$ \\
\hline Losartan & $150 \mathrm{mg} / \mathrm{d}$ & Inhibitor kanału If & Dawka docelowa \\
\hline Walsartan & $2 \times 160 \mathrm{mg} / \mathrm{d}$ & Iwabradyna & $2 \times 7,5 \mathrm{mg} / \mathrm{d}$ \\
\hline MRA & Dawka docelowa & & \\
\hline Spironolakton & $50 \mathrm{mg}$ & & \\
\hline Eplerenon & $50 \mathrm{mg}$ & & \\
\hline
\end{tabular}

2. Rozważ sakubitryl/walsartan u pacjentów z EF $\leq 35 \%$ z objawami II-IV klasy NYHA pomimo optymalnego standardowego leczenia farmakologicznego (ACEi lub ARB, B-adrenolityk, MRA), z ciśnieniem tętniczym skurczowym $\geq 100 \mathrm{mmHg}$, GFR $>30 \mathrm{ml} / \mathrm{min} / 1,73 \mathrm{~m}^{2}$, stężeniem potasu w surowicy $<5,4 \mathrm{mmol} / \mathrm{l}$. Leku nie należy łączyć z ACEi - pierwsza dawka sakubitrylu/walsartanu po $36 \mathrm{~h}$ od ostatniej dawki ACEi.

3. W okresie optymalizacji farmakoterapii MRA monitoruj GFR oraz stężenie $\mathrm{K}^{+}$przed każdym zwiększeniem dawki.

4. Rozważ iwabradynę u objawowych pacjentów w II-IV klasie NYHA z EF $\leq 35 \%$ leczonych standardową terapią HF, z rytmem zatokowym o częstości $\geq 75 /$ min pomimo stosowania maksymalnej tolerowanej dawki B-blokera lub u pacjentów, którzy nie tolerują B-adrenolityków.

5. Pacjenta z objawami HF pomimo optymalnego standardowego leczenia farmakologicznego przez 3 miesiące i z zespołem QRS $\geq 130$ ms oraz EF $\leq 35 \%$ skieruj do Poradni Kardiologicznej w celu kwalifikacji do implantacji CRT. Natomiast, jeśli w zapisie EKG zespół QRS jest <130 ms rozważ ICD.

6. Rozważ restrykcję płynową do $1,5-2 \mathrm{l} / \mathrm{dzień}$ oraz codziennie monitoruj masę ciała, przypomnij o konieczności ograniczenia spożycia soli ( $6 \mathrm{~g} / \mathrm{dzień})$.

7. Dostosuj dawki leków moczopędnych do potrzeb pacjenta. W sytuacji niskich wartości ciśnienia tętniczego rozważ zmniejszenie lub odstawienie leków moczopędnych, jeśli nie ma objawów przewodnienia. Natomiast w przypadku nasilenia duszności, obrzęków lub gwałtownego, niespodziewanego przyrostu masy ciała $>2 \mathrm{~kg}$ w ciągu 3 dni zwiększ dawki leków moczopędnych.

Rycina 2. Przykład „Listu do lekarza POZ” przedstawiającego zasady optymalizacji leczenia niewydolności serca z obniżoną frakcją wyrzutową HFrEFw okresie powypisowym (źródło [8]); POZ - podstawowa opieka zdrowotna 
Tabela 3. Zasady postępowania w okresie okołowypisowym (źródło [8])

\section{Pośrednie (wewnątrzszpitalne) \\ Rozpoznanie przyczyn i istotnych chorób współistniejących \\ Modyfikacja leczenia w celu zmniejszania objawów i zastoju oraz optymalizacji ciśnienia tętniczego \\ Wdrożenie leczenia i zwiekszanie dawek leków modyfikują- cych przebieg choroby \\ U odpowiednich pacjentów rozważenie wskazań do urządzeń wszczepialnych \\ Przy wypisywaniu ze szpitala i długoterminowe \\ Ustalenie planu dalszego postępowania z uwzględnieniem: \\ 1. schematu dalszego zwiększania dawek leków i monitoro- wania farmakoterapii \\ 2. potrzeby i odpowiedniego czasu ponownego rozważenia wskazań do zastosowania urządzeń wszczepialnych \\ 3. osoby przejmującej opiekę nad chorym i terminu kolejnej wizyty \\ Włączenie do programu opieki nad chorym z niewydolnością serca, edukacja i poradnictwo dotyczące odpowiednich mody- fikacji stylu życia \\ Zapobieganie wczesnym ponownym hospitalizacjom \\ Poprawa w zakresie objawów, jakości życia i przeżywalności}

że dla inhibitorów ACE jedynie 27\% chorych ambulatoryjnych z HFrEF osiągało dawkę docelową, dla ARB - 4\%, beta-adrenolityków - 17,7\%, a w przypadku MRA - 66\% [15]. W porównaniu z danymi światowymi polscy pacjenci rejestru QUALIFY częściej są leczeni rekomendowanymi w wytycznych standardowymi grupami leków (inhibitory ACE/ARB, beta-adrenolityki i MRA) za wyjątkiem iwabradyny (33\% wyniki baseline w świecie v. 13,9\% w Polsce) [15]. Na świecie już co 3. pacjent jest leczony iwabradyną, natomiast w Polsce stosuje się ją u co 7. ambulatoryjnego pacjenta z HFrEF, choć aż u 25\% polskiej populacji rejestru QUALIFY rejestrowano rytm zatokowy z częstością większą lub równą 75/min [15]. Ponadto jedynie 39,2\% chorych osiągało spoczynkową częstość rytmu serca poniżej 70/ min. Warto podkreślić, że dawkowanie iwabradyny nie jest skomplikowane (tab. 2), wymaga analizy rytmu w elektrokardiogramie i kontroli częstości rytmu w celu ustalenia dawkowania, co powinno pozostawać w gestii lekarza POZ czy kardiologa ambulatoryjnego. Terapia iwabradyną nie daje efektu „z odbicia”, jest bezpieczna metabolicznie dla pacjentów z przewlekłą chorobą obturacyjną płuc, przewlekłą chorobą nerek i u pacjentów z tendencją do hipotonii. Przyczyny niestosowania leków standardowej terapii HFrEF przedstawiono w artykule omawiającym wyniki rejestru QUALIFY [17].

Jednym z najważniejszych celów okresu powypisowego jest kontrola częstości rytmu serca [4]. Wyniki badania SHIFT (Systolic Heart Failure Treatment with the If Inhibitor Ivabradine Trial) wykazały 26-procentową redukcje ryzyka zgonu z powodu HF oraz 26-procentową redukcje liczby hospitalizacji z powodu zaostrzenia choroby w grupie pacjentów z HFrEF leczonych iwabradyną z rytmem zatokowym większym lub równym 70/min [17]. Istotne znaczenie częstości spoczynkowego rytmu serca w ustalaniu rokowania u chorych z HF potwierdzono również w badaniu EVEREST (The Efficacy of Vasopressin Antagonism in Heart Failure Outcome Study with Tolvaptan) $[18,19]$. Wykazano w nim, że wyższa częstość rytmu wiązała się z wyższym ryzykiem zgonu w pierwszych tygodniach po wypisaniu ze szpitala - każdy wzrost spoczynkowego rytmu serca o 5/min wiązał się z 13-procentowym wzrostem śmiertelności w 1. tygodniu po zakończeniu hospitalizacji oraz z 12-procentowym wzrostem śmiertelności w 4. tygodniu [19]. Zgodnie z wytycznymi ESC z 2016 roku w przypadku nieosiągnięcia optymalnej częstości rytmu

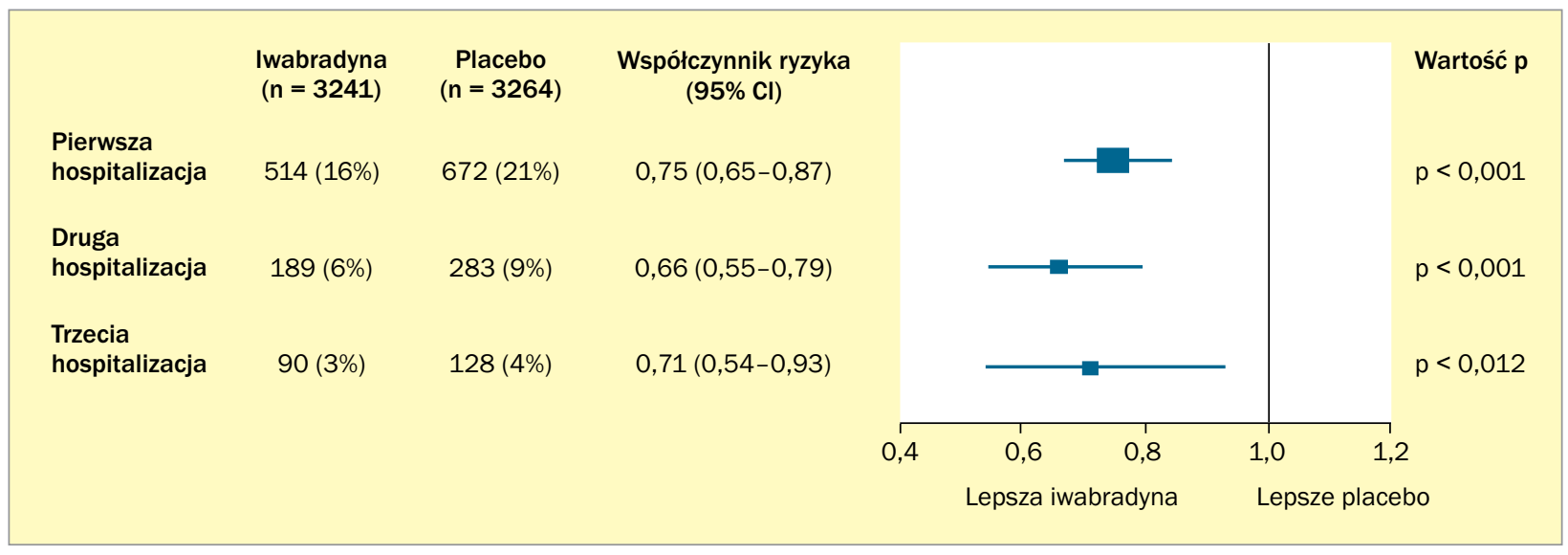

Rycina 3. Wpływ iwabradyny na częstość kolejnych hospitalizacji z powodu niewydolności serca - subanaliza badania SHIFT (Systolic Heart Failure Treatment with the If Inhibitor Ivabradine Trial) (na podstawie [20]) 
mimo zastosowania maksymalnej tolerowanej dawki beta-adrenolityku lub w sytuacji nietolerancji leku z tej grupy lub przeciwskazań do jego stosowania, zachodzi konieczność rozważenia dodatkowej terapii iwabradyną przy uwzględnieniu pozostałych warunków (rytm zatokowy $\geq 75 /$ ', EF $\leq 35 \%$ i objawy II-IV klasy według New York Heart Association [NYHA] mimo optymalnej standardowej terapii) (klasa zaleceń Ila, poziom wiarygodności danych B i C) [8].

Z kolei w przeprowadzonej subanalizie badania SHIFT oceniano wpływ iwabradyny na częstość kolejnych hospitalizacji z powodu HF i udokumentowano korzystny wpływ stosowania leku [20]. W badanej populacji częstość pierwszej rehospitalizacji zmniejszyła się o 25\%, w drugiej o 34\%, a w trzeciej o 29\% w porównaniu z grupą kontrolną (ryc. 3) [20]. Na potrzebe modyfikacji farmakoterapii w okresie powypisowym wskazują również wyniki rejestru OPTIMIZE, w którym udokumentowano, że u 2/3 chorych nie zmieniano dawki leku beta-adrenolitycznego w okresie 60-90 dni od wypisania [21].

W okresie powypisowym ważnym elementem postępowania terapeutycznego jest identyfikacja pacjenta do leczenia antagonistą receptora dla angiotensyny i inhibitorem neprilizyny (ARNI, angiotensin receptor-nephrilysin inhibitor) [8]. Zgodnie z wytycznymi ESC z 2016 roku sakubitril/walsartan należy proponować jako alternatywę dla inhibitora ACE u wykazujących objawy pacjentów w II-IV klasie niewydolności według NYHA z HFrEF mimo optymalnej standardowej terapii inhibitorami ACE/ARB, beta-adrenolitykami i MRA w celu dalszej redukcji ryzyka zgonów i ryzyka hospitalizacji z powodu HF (klasa zaleceń I, poziom wiarygodności danych $\mathrm{B})[8,22]$.

Okres powypisowy jest bardzo ważny dla podjęcia decyzji o zastosowaniu urządzeń wszczepialnych. Po 3 miesiącach standardowej terapii HFrEF w optymalnych tolerowanych dawkach należy ponownie ocenić wskazania do elektroterapii [8]. Mimo zwiększenia dostępności do urządzeń wszczepialnych nadal niski odsetek polskich chorych jest leczony elektroterapią, co potwierdziły wyniki rejestru QUALIFY (urządzenie do terapii resynchronizującej w funkcją defibrylacji (CRTD, cardiac resynchronization therapy with defibrillator) u 6,3\%, urządzenie do terapii resynchronizującej z funkcją stymulacji obu komór [CRT-P, cardiac resynchronization therapy with pacemaker) u 1,4\%, wszczepialny kardiowerter-defibrylator [ICD, implantable cardioverter-defibrillator] u 20,8\%) [15].

W okresie powypisowym problemem pozostaje przestrzeganie przez lekarzy wytycznych w zakresie stosowanych grup leków i ich dawek. W rejestrze QUALIFY wykazano, że niskie przestrzeganie zaleceń (dawki leków < 50\% dawki docelowej) w 6-miesięcznej obserwacji istotnie zwiększało śmiertelność całkowitą (HR 2,21, 95\% Cl 1,42-3,44; $p=0,001$ ], z przyczyn sercowo-naczyniowych (HR 2,27, $95 \% \mathrm{Cl} 1,36-3,77 ; p=0,003$ ), zgony w powodu HF (HR 2,26, 95\% Cl 1,21-4,2; $p=0,032)$, hospitalizacje i zgony w powodu HF (HR 1,26, 95\% Cl 1,08-1,71; $p=0,024)$ oraz hospitalizacje i zgony z przyczyn sercowo-naczyniowych (HR 1,35, 95\% Cl 1,08-1,69, p = 0,013) [23].

Jednym z najważniejszych elementów długoterminowego leczenia HF jest edukacja chorych [8]. Już w trakcie hospitalizacji wyszkolony personel powinien zapewnić pacjentowi i jego rodzinie informacje o jednostce chorobowej i edukację w zakresie samokontroli. Najlepszą opcją jest objęcie pacjentów z HF wielodyscyplinarnymi programami leczenia [8]. W celu edukacji pacjenta i rodziny oraz uzyskania dodatkowych informacji na temat HF zaleca się korzystanie z portalu internetowego www.slabeserce.pl

\section{Podsumowanie}

Okres okołowypisowy jest kluczowym elementem postępowania dla pacjenta hospitalizowanego z powodu HF. Optymalne postępowanie terapeutyczne z wczesnym zastosowaniem leków modyfikujących przebieg HF (inhibitorów ACE/ARB, beta-adrenolityków, MRA i iwabradyny) i dawek docelowych oraz kompleksowa, multidyscyplinarna opieka w okresie okołowypisowym powodują zmniejszenie częstości ponownych hospitalizacji oraz poprawę przeżycia pacjentów z HFrEF.

\section{Konflikt interesów}

Udział w rejestrze QUALIFY.

\section{Abstract}

Patients after hospitalisation due to acute heart failure (HF) have higher risk of mortality and rehospitalisations, especially in the 60 to 90 days after the discharge. Every HF hospitalisation worsens prognosis and increases risk of death in HF patients. The discharge and early phase after the discharge with treatment modified HF is crucial in prevention of HF hospitalisation. This article presents the current knowledge how to manage in the discharge period and in the early phase after the discharge from hospital.

Key words: heart failure, discharge management

Folia Cardiologica 2018; 13, 4: 371-377 


\section{Piśmiennictwo}

1. OECD Health Statistics 2017. Dostępne: http://www.oecd.org /els/ /health-systems/health-data.htm

2. Niewydolność serca w Polsce - raport 2016. Materiały informacyjne Sekcji Niewydolności Serca PTK. Dostępne: http://www.niewydolnoscserca.pl/barometr.pdf. http://www.niewydolnosc-serca.pl/barometr. pdf (15.07.2018).

3. Solomon SD, Dobson J, Pocock S, et al. Candesartan in Heart failure: Assessment of Reduction in Mortality and morbidity (CHARM) Investigators. Influence of nonfatal hospitalization for heart failure on subsequent mortality in patients with chronic heart failure. Circulation. 2007; 116(13): 1482-1487, doi: 10.1161/CIRCULATIONAHA.107.696906, indexed in Pubmed: 17724259.

4. Yilmaz MB. A. Mebazaa. Definition and characteristics of the vulnerable phase in heart failure. Medicographia. 2015; 37: 139-143.

5. Matyjas K, Lelonek M. Pacjent z niewydolnością serca w okresie vulnerable phase. Folia Cardiol. 2018; 13(1): 71-78, doi: 10.5603/ /fc.2018.0014.

6. Mebazaa A, Yilmaz MB, Levy P, et al. Recommendations on pre-hospital \& early hospital management of acute heart failure: a consensus paper from the Heart Failure Association of the European Society of Cardiology, the European Society of Emergency Medicine and the Society of Academic Emergency Medicine. Eur J Heart Fail. 2015; 17(6): 544-558, doi: 10.1002/ejhf.289, indexed in Pubmed: 25999021.

7. Mueller C, Christ M, Cowie M, et al. Acute Heart Failure Study Group of the ESC Acute Cardiovascular Care Association. European Society of Cardiology-Acute Cardiovascular Care Association Position paper on acute heart failure: A call for interdisciplinary care. Eur Heart J Acute Cardiovasc Care. 2017; 6(1): 81-86, doi: 10.1177/2048872615593279, indexed in Pubmed: 26124458.

8. Ponikowski P, Voors AA, Anker SD, et al. Authors/Task Force Members, Document Reviewers. 2016 ESC Guidelines for the diagnosis and treatment of acute and chronic heart failure: the Task Force for the diagnosis and treatment of acute and chronic heart failure of the European Society of Cardiology (ESC). Developed with the special contribution of the Heart Failure Association (HFA) of the ESC. Eur J Heart Fail. 2016; 18(8): 891-975, doi: 10.1002/ejhf.592, indexed in Pubmed: 27207191.

9. DeVore AD, Mi X, Mentz RJ, et al. Discharge heart rate and $\beta$-blocker dose in patients hospitalized with heart failure: findings from the OPTIMIZE-HF registry. Am Heart J. 2016; 173: 172-178, doi: 10.1016/j. ahj.2015.10.026, indexed in Pubmed: 26920611.

10. Hidalgo FJ, Anguita M, Castillo JC, et al. Effect of early treatment with ivabradine combined with beta-blockers versus beta-blockers alone in patients hospitalised with heart failure and reduced left ventricular ejection fraction (ETHIC-AHF): A randomised study. Int J Cardiol. 2016; 217: 7-11, doi: 10.1016/j.ijcard.2016.04.136, indexed in Pubmed: 27167103.

11. Lopatin YM, Cowie MR, Grebennikova AA, et al. Optimization of heart rate lowering therapy in hospitalized patients with heart failure: Insights from the Optimize Heart Failure Care Program. Int J Cardiol. 2018; 260: 113-117, doi: 10.1016/j.ijcard.2017.12.093, indexed in Pubmed: 29622423.

12. Ryan J, Kang S, Dolacky S, et al. Change in readmissions and follow-up visits as part of a heart failure readmission quality improvement initiative. Am J Med. 2013; 126(11): 989-994.e1, doi: 10.1016/j. amjmed.2013.06.027, indexed in Pubmed: 24054174.

13. Bradley EH, Sipsma H, Horwitz LI, et al. Hospital strategy uptake and reductions in unplanned readmission rates for patients with heart failure: a prospective study. J Gen Intern Med. 2015; 30(5): 605-611, doi: 10.1007/s11606-014-3105-5, indexed in Pubmed: 25523470.

14. Metra M, Gheorghiade M, Bonow RO, et al. Postdischarge assessment after a heart failure hospitalization: the next step forward. Circulation. 2010; 122(18): 1782-1785, doi: 10.1161/CIRCULATIONAHA.110.982207, indexed in Pubmed: 20956215.

15. Opolski G, Ozierański K, Lelonek M, et al. Adherence to the guidelines on the management of systolic heart failure in ambulatory care in Poland. Data from the international QUALIFY survey. Pol Arch Intern Med. 2017; 127(10): 657-665, doi: 10.20452/pamw.4083, indexed in Pubmed: 28786405.

16. Lelonek M. Niewydolności serca z obniżoną frakcją wyrzutową lewej komory - jakich informacji dostarczył rejestr QUALIFY? Folia Cardiol. 2018; 13(3): 259-262, doi: 10.5603/fc.2018.0050.

17. Swedberg K, Komajda M, Böhm M, et al. SHIFT Investigators. Ivabradine and outcomes in chronic heart failure (SHIFT): a randomised placebo-controlled study. Lancet. 2010; 376(9744): 875-885, doi: 10.1016/S0140-6736(10)61198-1, indexed in Pubmed: 20801500.

18. Böhm M, Borer J, Ford I, et al. Heart rate at baseline influences the effect of ivabradine on cardiovascular outcomes in chronic heart failure: analysis from the SHIFT study. Clin Res Cardiol. 2013; 102(1): 11-22, doi: 10.1007/s00392-012-0467-8, indexed in Pubmed: 22575988.

19. Greene SJ, Vaduganathan M, Wilcox JE, et al. EVEREST Trial Investigators. The prognostic significance of heart rate in patients hospitalized for heart failure with reduced ejection fraction in sinus rhythm: insights from the EVEREST (Efficacy of Vasopressin Antagonism in Heart Failure: Outcome Study With Tolvaptan) trial. JACC Heart Fail. 2013; 1(6): 488-496, doi: 10.1016/j.jchf.2013.08.005, indexed in Pubmed: 24622000.

20. Borer JS, Böhm M, Ford I, et al. SHIFT Investigators. Effect of ivabradine on recurrent hospitalization for worsening heart failure in patients with chronic systolic heart failure: the SHIFT Study. Eur Heart J. 2012; 33(22): 2813-2820, doi: 10.1093/eurheartj/ehs259, indexed in Pubmed: 22927555.

21. Fonarow GC, Abraham WT, Albert NM, et al. Dosing of beta-blocker therapy before, during, and after hospitalization for heart failure (from Organized Program to Initiate Lifesaving Treatment in Hospitalized Patients with Heart Failure). Am J Cardiol. 2008; 102(11): 1524-1529, doi: 10.1016/j.amjcard.2008.07.045, indexed in Pubmed: 19026308.

22. McMurray JJV, Packer M, Desai AS, et al. PARADIGM-HF Investigators and Committees. Angiotensin-neprilysin inhibition versus enalapril in heart failure. N Engl J Med. 2014; 371(11): 993-1004, doi: 10.1056/ /NEJMoa1409077, indexed in Pubmed: 25176015.

23. Komajda M, Cowie MR, Tavazzi L, et al. QUALIFY Investigators. Physicians' guideline adherence is associated with better prognosis in outpatients with heart failure with reduced ejection fraction: the QUALIFY international registry. Eur J Heart Fail. 2017; 19(11): 1414-1423, doi: 10.1002/ejhf.887, indexed in Pubmed: 28463464. 